保健物理，12，195 197（1977）

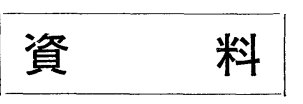

\title{
THE MASTER OF SCIENCE PROGRAM IN HEALTH PHYSICS IN THE REPUBLIC OF CHINA ${ }^{\dagger}$
}

\author{
Pao-Shan WENG*1
}

(Received April 20, 1977)

The M.S. program in health physics in the Republic of China started at the Graduate School of National Tsing Hua University on September, 1, 1975. This program was evolved from the experiences gained during the past decade. Several training courses and inspections of radiation facilities throughout Taiwan have been held year by year. The newly established M.S. program will enable one to work in three distinct areas: nuclear power plant, hospital, and radiation biology with reference to radiation protection. Basic scientific knowledge and experimental technique are equally emphasized. The student should study at least for two years and submit a M.S. thesis to complete his degree program.

\section{INTRODUCTION}

An important activity of National Tsing Hua University (NTHU) is the promotion of training in health physics and radiation protection. Through its organized training courses, its facilities, and its field experts, NTHU has assisted many organizations in training essential groups of scientists, engineers, and technicians in health physics and radiation protection. During the past decade, 60 persons participated in two health physics training courses and 197 persons participated in ten radiation protection training courses. Each course might last from one week to one month. Emphasis was placed upon concentrated systematic and practical training.

\footnotetext{
$\uparrow$ This report was based on the material presented at the Health Physics Society 21st Annual Meeting, San Francisco, 20 June-2 July (1976).

*1 翁寶山, 国立清華大学; 中華民国台湾省新竹市 Health Physics Section, National Tsing Hua University; Hsinchu, Taiwan 300, Republic of China.
}

As a result of the rapid development of nuclear energy utilization on Taiwan, the demand of health physicists is significant. The rapidly growing medical practice of Taiwan in recent years has also changed the status of health physics. A survey or radiological radiation sources was performed in 1970 and a similar survey of industrial radiation sources was. also performed recently. ${ }^{1)}$ The results are listed in Table 1 up to January 19, 1976 where the Institute of Nuclear Energy Research (INER) of our Atomic Energy Council (AEC) is not included. The INER is a medium size nuclear research establishment with a $40 \mathrm{MW}$ CANDU type reactor as its. main nuclear facility. A summary report on the health physics development and radiation protection experience in the Republic of China is given elsewhere $^{2)}$

\section{THE MASTER OF SCIENCE PROGRAM}

As there is a growing need for comprehensive training in health physics, in line with the rapid development of nuclear energy program, a two-year program leading to the M.S. degree in health physics 
Table 1 Number of radiation sources and workers up to January 19, 1976.*

\begin{tabular}{|c|c|c|c|c|c|}
\hline & Radiation source & Number & $\begin{array}{l}\text { Hospital, clinic, } \\
\text { or organization }\end{array}$ & Physician & Technician \\
\hline \multirow[t]{7}{*}{1.} & Medical & & & & \\
\hline & $\mathrm{X}$-ray diagnostic & 1391 & 1004 & 1004 & 1420 \\
\hline & X-ray therapeutic & 16 & 16 & 16 & 18 \\
\hline & $\gamma$-ray teletherapeutic, ${ }^{60} \mathrm{Co}$ & 15 & 13 & 13 & 19 \\
\hline & $\gamma$-ray teletherapeutic, ${ }^{137} \mathrm{Cs}$ & 2 & 2 & 2 & 3 \\
\hline & $\gamma$-ray brachy therapeutic, ${ }^{226} \mathrm{Ra}$ & 102 & 28 & 28 & 42 \\
\hline & $\beta$-ray brachy therapeutic, ${ }^{90} \mathrm{Sr}$ & 30 & 30 & 30 & 28 \\
\hline \multirow[t]{4}{*}{2.} & Non-medical & & & & \\
\hline & $\mathrm{X}$-ray, industrial radiographic & 197 & 152 & & 206 \\
\hline & $\begin{array}{l}\gamma \text {-ray, industrial radiographic, and } \\
\text { testing, }{ }^{60} \mathrm{Co},{ }^{137} \mathrm{Cs},{ }^{192} \mathrm{Ir},{ }^{85} \mathrm{Kr}\end{array}$ & 168 & 48 & & 188 \\
\hline & $\begin{array}{l}\text { Nuclear facilities at NTHU, nuclear } \\
\text { reactors, accelerators, radioisotope } \\
\text { production, radioactive waste disposal }\end{array}$ & & 1 & & 95 \\
\hline \multirow[t]{2}{*}{3.} & $\begin{array}{l}\text { Medical and non-medical } \\
\text { radioisotopes, }{ }^{131} \mathrm{I},{ }^{125} \mathrm{I},{ }^{3} \mathrm{H},{ }^{99} \mathrm{Mo}-{ }^{99} \mathrm{~m} \mathrm{Tc} \\
{ }^{14} \mathrm{C},{ }^{35} \mathrm{~S},{ }^{32} \mathrm{P} \text {, etc. }\end{array}$ & & 29 & 29 & 31 \\
\hline & Total & 1921 & 1323 & 1122 & 2050 \\
\hline
\end{tabular}

* The employees of INER and the students of NTHU are excluded.

started in September 1975 at NTHU. This is a complete and systematic training for senior health physics specialists or qualified persons who will work in the field of radiation protection particularly for the nuclear power plants, hospitals, and radiobiological research.

The introduction of such broad training programs involves nuclear physics, isotope chemistry, radiation dosimetry, radiation protection measures, radiobiological research, and nuclear technology which are available at NTHU. This program will include not only lectures but also many practical exercises and research.

In general, our specific curriculum in the M.S. degree program in health physics contains the following three components:

1. Basic scientific knowledge.

2. Principles and techniques of radiation protection.

3. General information on associated subjects.
In practices, these three components are combined or fused with one another, with the relative weight placed on each depending on the purpose and category of the specific requirements of Taiwan industry and medical practice, and the students being trained.

The range of subjects to be covered in an M.S. degree program varies widely according to the educational background of students and instructors as well. The curriculum shown below is the suggested standard curriculum:

1. Mathematics beyond calculus plus computer techniques.

2. Atomic, nuclear, and radiological physics.

3. Radiation detectors and associated equipment.

4. Radiation and isotope chemistry.

5. Radiation biology and human physiology.

6. Principles of health physics.

7. Practical health physics.

8. Administrative, legal, regulatory aspects, and emergency procedures. 
9. Special topics such as medical and industrial aspects, and nuclear energy utilization.

10. Seminar and thesis.

In general, health physics and radiation protection is a newly explored field of science and technology and also related to many different activities, such as research, practical work, technical consultant, safeguard, administration, etc. At the present stage of development of the utilization of nuclear energy in Taiwan, NTHU will undertake the introductory, supplementary, and advanced training in health physics and radiation protection.

Presently there are six first-year graduate students in health physics, four with nuclear engineering background, one with physics background, and one with chemistry background. Of the six first-year graduate students one is female, and five are male.

The research topics being carried out by six firstyear graduate students are:

1. Gamma-ray induced biological effect in mice.

2. X-ray induced biological effect in mice.

3. Consequence of effluent release.

4. Separation of radionuclides from environmental samples.

5. Thermoluminescent dosimeters for neutron detection.

6. Wholebody counting technique.

In the next decade, we are engaged in ten major construction projects which will be described below. The demand of health physicists with advanced degree is anticipated.

\section{TEN MAJOR CONSTRUCTION PROJECTS}

The ten major construction projects being carried out by the government of Republic of China are all important undertakings aimed at building substantial chemical industries and expanding the transportation and power capacity of the nation. They are :

1. Nuclear power plants project.

The present installed capacity of electric power system on Taiwan is 5,000 MW. By 1983, it would exceed 10,700 MW of which almost one half would be nuclear power. The six nuclear units to be put into service between 1977 and 1984 are as follows:

\begin{tabular}{|c|c|c|c|c|}
\hline Power station & $\begin{array}{l}\text { Unit } \\
\text { No. }\end{array}$ & Type & MW (e) & $\begin{array}{l}\text { Commissioning- } \\
\text { year }\end{array}$ \\
\hline \multirow{2}{*}{$\begin{array}{c}\text { First } \\
\text { (Chin Shan) }\end{array}$} & $\int 1$ & BWR & 636 & 1977 \\
\hline & 2 & BWR & 636 & 1978 \\
\hline \multirow{2}{*}{$\begin{array}{c}\text { Second } \\
\text { (Kuo Sheng) }\end{array}$} & $\int 3$ & BWR & 985 & 1980 \\
\hline & 4 & BWR & 985 & 1981 \\
\hline \multirow{2}{*}{$\begin{array}{c}\text { Third } \\
\text { (Ma An Shan) }\end{array}$} & $\int 5$ & PWR & 951 & 1983 \\
\hline & $\{6$ & PWR & 951 & 1984 \\
\hline
\end{tabular}

2. The Taiwan area north-south freeway project.

3. The modern air transportation center project.

4. The Taichung harbor project.

5. The Taiwan railway trunk line electrification project.

6. The petrochemical industry long project.

7. The giant shipyard project.

8. The big integrated steel mill project.

9. The Taiwan north link railway project.

10. The Port of Suao project.

\section{MANPOWER PROJECTION}

In addition to ten major construction projects. mentioned above, several nuclear medicine departments will be installed in the major hospitals of Taiwan, and so are the linear accelerators and teletherapeutic units such as ${ }^{60} \mathrm{Co}$. A preliminary analysis indicates that during the first five years a total of 25 health physicists are needed in Taiwan. We are planning to train five to eight health physicists each year during the next decade. As. the curriculum indicated, our health physics graduates will be able to work in three distinct areas: nuclear power plant, hospital, and radiobiological research. We are looking for international cooperation in expediting our health physics educational. program and research, and would exchange any information related to our training with institutions. and laboratories in other countries.

\section{REFERENCES}

1) P.S. Weng, Nucl. Sci J. (Taiwan), 12, 109 (1975).

2) P.S. Weng; C.N. Cheng, V.H. Wei and K. Y. LiU; Health Phys., 23, 549 (1972). 